\title{
ERRATUM TO: COLLECTIVE MEMORY, A FUSION OF COGNITIVE MECHANISMS AND CULTURAL PROCESSES
}

\author{
Aaron V. Cicourel
}

Erratum to: Revue de synthèse DOI 10.1007/s11873-014-0258-7

First page. The author's institutional affiliation is erroneous due to an alteration during the editorial and publication process.

Aaron V. Cicourel is indeed Professor Emeritus at the University of California, San Diego and at the University of California, San Francisco.

The Revue de synthèse apologizes to the author and to the institutions concerned. 